\title{
RESEARCH PAPER \\ Factors that affect fruit consumption in schools of the Metropolitan Region (Chile): The case of two schools in the district of Lo Prado
}

\author{
Andre Beaujanot, Guillermo Donoso, and Andrea del Valle \\ Departamento de Economía Agraria, Facultad de Agronomía e Ingeniería Forestal, Pontificia Universidad \\ Católica de Chile, Casilla 306-22, Santiago, Chile.
}

\begin{abstract}
A. Beaujanot, G. Donoso, and A. del Valle. 2012. Factors that affect fruit consumption in schools of the Metropolitan Region (Chile): The case of two schools in the district of Lo Prado. Cien. Inv. Agr. 39(1): 19-35. This research identifies the influence of environmental, social and consumer habits on decision making of children's fruit consumption. The characteristics that influence children's fruit consumption in school and their willingness to change these consumption behaviors are also studied. The study is performed on $5^{\text {th }}$ and $8^{\text {th }}$ grade students who attend public and private elementary schools in the municipality of Lo Prado, Santiago. The level of fruit consumption significantly depends on the family and school support that children receive. Statements such as: "Fruits are good for my health" and "Fruits are rich in vitamins" are very important for parents and children who attend private and public schools. From a strategic point of view, this research concludes that a more proactive and consistent approach is needed from parents and school communities to encourage fruit consumption among children. This approach results in either maintaining or improving children's fruit consumption as they grow older. Also, the actions of parents and schools towards the preparation of desserts using fruits are proven to be an effective way to increase fruit consumption.
\end{abstract}

Key words: Determinants of fruit consumption among children, Children's eating habits, Children's fruit and vegetable intake.

\section{Introduction}

The rapidly increasing obesity in children and teenagers has raised concerns about the causes of this phenomenon. From a human life cycle perspective, the causes of obesity start at an early age (Moreno et al., 2011), so the study of factors that affect fruit and vegetable consumption is a

Received March 23, 2010. Accepted July 21, 2011. Corresponding author: gdonosoh@uc.cl public health priority in order to take measures to prevent obesity in children and adolescents.

The obesity and overweight problems, developed from poor eating habits at an early age, are health problems of great relevance worldwide, with an upward trend particularly in developing countries and in those more developed, such as Argentina, China, Brazil and Chile (World Bank, 2011; Palou et al., 2011). Melendez (2008) described that global obesity and overweight in schools has reached levels of 2.7 and $7.6 \%$, respectively, 
while in America, they have reached 8.2 and $23.6 \%$, respectively.

In Chile, statistics show an increase in the obesity rate among children entering first grade in public schools (JUNAEB, 2009), indicating that childhood obesity in the country has nearly tripled among this group of children, from 7\% in 1987 to almost 20\% in 2006 (Kain et al., 2007).

The diversity of factors involved in the consumption of food has resulted in two specific and independent but interrelated study areas: dietary intake and eating habits. Dietary intake is focused on the amount and types of food in the diet (Dominguez-Vasquez et al., 2008). Vasquez et al. (2004) investigated the dietary intake and its relationship with obesity in school-age children and concluded that children are exposed to a high fat intake at home, while child daycares protected children regarding their energy intake. Thus, it is urgent to educate parents on food and nutrition regarding children's dietary intake at home.

The second area of the study and the focus of this study, eating habits, concentrate on the set of actions that define the relationships between people and food. It is generally accepted that food habits are acquired through direct experience with food, imitation of role models, food availability, social status, emotional symbolism and cultural traditions. Eating habits are influenced by factors related to the individual (Osorio et al., 2002), parents (Lopez et al., 2004) and by the environment (Dominguez - Vásquez et al., 2008, Patrick and Niklas, 2005, Barnard and Eyres, 1979). However, as described by Martin (2007), these risk factors are modifiable, so they must be further studied to understand them and to be able to establish public policies that address this growing problem.

There are numerous international studies that have focused on identifying the eating habits of adolescents and children (Droog et al., 2011, Bower and Ferguson, 2008; Dominguez-Vasquez et al., 2008, Gilbert et al., 2007; Reinaerts et al.,
2006, Patrick and Nicklas, 2005, Lopez et al., 2004, French and Stables, 2003, Nasrin et al., 2003, Diaz, 2002; Cervantes et al., 1996).

Nasrin et al. (2003) investigated the relationship between behavioral, cognitive, personal and environmental factors and low fruit and vegetable intake among adolescents in the city of Tehran, Iran. In this study, the authors found that food preferences established during middle adolescence persist into adulthood, so it is important to motivate a change in fruit and vegetable consumption patterns at earlier stages of adolescence. The authors concluded that fruit and vegetable intake among adolescents is affected by variables that are beyond their control, such as the availability of fruits and vegetables, which, in turn, is affected by the socioeconomic status of their families and the education level of their parents.

French and Stables (2003) reviewed studies on environmental interventions intended to help promote the consumption of fruits and vegetables among children. The study found that factors such as price, availability and effective promotion of fruits and vegetables lead to greater or reduced consumption of these foods in children. Droog et al. (2011) investigated the influence of brand characters on the fruit consumption decisions among children. Their results showed that the use of brand characters like Dora the Explorer or Sponge Bob increased the desire to purchase healthy fruit-based products. Also, several other studies confirmed that the promotion (advertising) of food profoundly determines children's preferences, for both food and brand types (Herrero, 2008). Children are easily persuaded by advertisements, which influence the demands they make to their parents. While children and young people are informed about certain health topics by the media, it is fragmented and limited; some researchers have described this information as scarce and disjointed. These results have clear implications for policies that promote healthy product consumption among children. 
Factors such as familiarity with a certain food, increased exposure, and increased accessibility have a significant impact on children's fruit and vegetable preferences (Burchett, 2003). Also, the same author found that the "healthy" perception of food has a negative correlation with children's food preferences.

Social factors that are associated with fruit and vegetable intake among children were investigated by Reinaerts et al. (2006). Their results indicated that factors such as preferences, education regarding fruit and vegetable consumption by teachers and parents, and the ready to eat availability of these foods at home and at school affect fruit and vegetable intake. Also, the study emphasized that both children and parents have a favorable attitude towards activities that promote the consumption of fruits and vegetables; however, most parents are not willing to take an active role in these activities.

Bower and Ferguson (2008) conducted a study in the Edinburgh primary schools (United Kingdom) to determine the perception that children have about fresh fruit and "fruit snacks" as school meals. The results indicated that children perceive fruits as friendly, healthy, affordable and available, but they are not suitable as school snacks because they easily acquire bruises. However, one solution to the deterioration in the quality of fruits and vegetables is represented by minimally processed fruits and vegetables. Currently, there are significant technological developments that can reduce this quality problem.

In Chile, studies on fruit and vegetable intake motivation among children are limited and only provide certain indications on the attitudes about consumption of these foods, showing that there is low fruit intake among this population (Olivares et al., 2007, 2005, 1999; Olivares and Bustos, 2006, Osorio et al., 2002, Yanez et al., 2001, Kain et al., 2001; Atalah et al., 1999). Olivares et al. (2005) indicated that the causes of this low level of consumption have not been sufficiently studied.
This study contributes to the discussion about the influence of factors that affect eating behaviors among school-age children in Chile. The main objective of this study was to investigate the influence of environmental, social and consumer behavior factors on fruit-eating habits among children. The second objective was to investigate the willingness to change the behaviors of fruit intake among school children and their parents. Both goals were studied in a group of students and parents from two schools in the Metropolitan Region of Chile, a public school and a co-funded school.

\section{Materials and methods}

The study was based on information gathered in two schools that provide primary education in the district of Lo Prado in the Metropolitan Region of Chile (Latitude: -33.4333, Longitude: -70.7833). The population of this community is 107,845 inhabitants, distributed in 27,565 households, with an average of 3.9 persons per household. The monthly family income is $\$ 503,932$ (U.S. $\$ 1,008$ ). This district has a $44.7 \%$ coverage of preschool education and a $100 \%$ coverage of elementary education (MIDEPLAN, 2002).

The study population consisted of students, boys and girls, from $5^{\text {th }}$ to $8^{\text {th }}$ grades (between 10 and 14 years of age). Also, the parents of the students were interviewed.

The first school corresponds to a public school, which provides elementary schooling, starting from kindergarten through 8 th grade. It has 473 students divided into one class per grade up to $5^{\text {th }}$ grade, then two classes per grade until the $8^{\text {th }}$ grade. The school is free and is funded by government contributions (MINEDUC, 2009). The second school in this study is co-funded. It also provides elementary schooling, starting from pre-school through $8^{\text {th }}$ grade. It has 483 students divided into two classes per grade. This school is financed by contributions from the state and 
economic contributions from parents and guardians who pay a monthly fee (MINEDUC, 2009).

The sample size was determined following the methodology proposed by Cochran (1963), under the assumption of maximum variance and considering a sampling error of $5 \%$. The studied group corresponds to the total number of students attending each school, from the $5^{\text {th }}$ to the $8^{\text {th }}$ grade. The total number is 185 and 240 for the public and co-funded schools, respectively.

The principals of both schools supported this study. Also, the children and their parents were informed of the research objectives and purpose of the applied survey. The sample corresponded to the group of children and parents who agreed to participate, once they were informed.

The estimated sample size was 125 students for the public school and 148 students for the co-funded school. The numbers of students surveyed per class were selected in proportion to the number of students attending each school. In addition to the students, their parents were also interviewed. For children of the public school, 125 surveys were administered on October 29 and 30, 2008, and on November 3, 2008, all of the surveys were validated for further analysis. In the public school, surveys were sent to the parents with the children on the day they were surveyed to be returned the following day. A total of 62 surveys were returned out of the 125 that were sent, a response rate of $49.6 \%$. From the surveys submitted by parents, only 53 were suitable for analysis. As described by Babbie (2000), a response rate of 50\% is appropriate for analysis and to develop reports, a response rate of $60 \%$ is good and a rate of $70 \%$ is very good.

In the case of the co-funded school, 148 surveys were administered to the children on October 27, 2008; all of the surveys were validated for further analysis. As in the public school, surveys were sent to the parents with their children on October 27 of that year. One hundred twenty- eight completed surveys were answered by the parents, equivalent to a response rate of $86.5 \%$. From this subtotal, only 118 surveys were suitable for further analysis.

Four focus groups were conducted to explore the important variables and features among children regarding fruit intake, eating habits, behaviors and beliefs. The potential participants of the focus groups (school children and their parents) were informed about the objectives of the research and focus group. Once informed, children and parents, who agreed to participate, constituted four focus groups. The study and its methodology were approved by the principals of both schools.

The first focus group was composed of 8 children attending $5^{\text {th }}$ and $6^{\text {th }}$ grade (10 to 13 years old). The second focus group was composed of 8 children attending $7^{\text {th }}$ and $8^{\text {th }}$ grade (12 to 15 years). Finally, the third and fourth focus groups consisted of one parent for each child of groups 1 and 2. The focus group moderator, who recorded the sessions and wrote down the behaviors of the participants facing the questions, used a questionnaire to determine the most important factors for both the children and parents that influence eating behaviors among children (more information about the questions and conducting the focus groups can be found in del Valle, 2009).

Questions were asked regarding the children's eating habits and factors influencing these habits. To determine the eating behaviors of the children, the children were asked about their favorite foods or meals, what foods they ate at different times, such as recess, lunch and dinner, how they regulate the consumption of sweets and if they regularly consumed fruits and vegetables. Factors that influenced the investigated behaviors are those that are associated with promotion, disclosure of food characteristics and healthy lifestyles, such as playing sports.

The surveys were elaborated based on the results of the focus groups and literature review. The surveys were tested through pre-surveys ap- 
plied to school children and their parents. These pre-surveys measured the understanding of the questions and corrected formatting details and failure to understand. Three $5^{\text {th }}, 6^{\text {th }}, 7^{\text {th }}$ and $8^{\text {th }}$ grade volunteers from the co-funded school and their parents participated in this process, which took place on October 6-7, 2008.

The designed surveys were divided into three sections. The first section aims to measure the perceptions of respondents on 14 statements, labeled LS1 to LS14, reflecting possible thoughts of parents and students regarding eating habits. All measurements were based on Likert scales from 1 to 7 for each statement, where 1 meant strongly disagree and 7 meant totally agree. The second section measured the degree of relative importance of the characteristics associated with fruit intake among the students and parents. The last section of the survey collected information on the propensity towards changing fruit consumption habits in both children and parents using external stimuli.

A preliminary analysis of the survey data was considered. A first moment estimator around zero (measures of central tendency as mean), and estimators of the second, third and fourth moment around the mean (measures of dispersion such as standard deviation, and distribution such as skewness and kurtosis) were used to assess the normality of the sample data.

A cluster analysis was performed to study the family influence on the consumption decision among children in the study, how the school where children study influences fruit consumption and how the children's fruit consumption habits have influenced the decision to consume these foods.

A Chi-square test was performed to determine whether there is a significant association between the consumption frequencies among children and the cluster to which they belong.

To measure the relative importance of the factors that could affect fruit consumption among the respondents, the Best Worst (BW) methodology was used. This methodology was originally introduced by Finn and Louviere in 1992, and it is used in fields as diverse as marketing business research (e.g. Analysis Software), health and ethics, among others (Lusk and Briggeman, 2009). The BW method asks people to choose the best and worst stimulus available from a set of options. This method provides more information than the method of paired comparison and requires a smaller number of responses to the issues discussed (Jaeger and Cardello, 2009). The application of this methodology results in a scale that reflects the most and least important aspects at the time of eating fruits, both among children and their parents. This study used an incomplete block design in the Best-Worst method, as employed by Auger et al. (2004). This type of design ensures that each aspect appears four (4) times in all choice sets, and within each set, each pair of aspects is listed only once.

\section{Results and discussion}

The sample distribution surveyed in each school is as follows: At the public school, the largest number of surveys were conducted on $7^{\text {th }}$ grade children (35\%), followed by $6^{\text {th }}$ and $8^{\text {th }}$ graders $(27 \%)$, and finally, $5^{\text {th }}$ graders $(11 \%)$. The sampling distribution per school year in the co-funded school was more uniform, with $25.7 \%$ of the sample for $5^{\text {th }}$ graders, $26.3 \%$ for $6^{\text {th }}$ graders and $23 \%$ and $25 \%$ for $7^{\text {th }}$ and $8^{\text {th }}$ graders, respectively. The sampling distribution showed similar patterns regarding the school year, but the co-funded school presented a more homogeneous distribution regarding age than the public school.

Regarding the educational level of the parents, there were differences in the sampling distribution between the two educational institutions. Most of the parents surveyed have had formal education; $94.3 \%$ in the public school and $67.8 \%$ in the cofunded school. However, there are differences in the distribution of primary and secondary education for both educational institutions. For public schools, 
$47 \%$ of the parents had elementary education, $47 \%$ had secondary education, $4 \%$ had technical education and $2 \%$ had college education. No parents surveyed said that they had done graduate studies. In the co-funded school, however, $15 \%$ of the parents finished elementary education, $52 \%$ had secondary education, $29 \%$ had technical education, $5 \%$ had college education and $0.9 \%$ said that they had done graduate studies. Therefore, the parents of the children attending the co-funded school presented higher levels of education compared to the parents of the public school.

The sampling distribution by gender showed significant differences between the children and parents. For children, $47.9 \%$ were boys versus $52.1 \%$ girls. This distribution is consistent with the gender distribution of the Chilean population, which is $49.3 \%$ men and $50.7 \%$ women (INE, 2002). However, most of the valid questionnaires from the parents were answered by mothers, approximately $87.3 \%$ of the surveyed parents.

Skewness and kurtosis estimators for all variables are within normal ranges. Kline (1998) described that asymmetry values less than 3 and kurtosis values less than 8 indicate that the variables are normally distributed. None of the variables exceeded this limit (Table 1). Therefore, it was concluded that the data are normally distributed, indicating that further statistical analysis, such as ANOVA, can be performed properly.

From the 444 surveys administered to the parents and students from both schools, $14.2 \%$ said they eat fruit once a week, $31.1 \%$ do so 2-3 times a week, $28.2 \%$ eat fruit 4 to 5 times a week and $26.6 \%$ eat fruit 6 to 7 times a week. When analyzing the frequency of students and parents separately, approximately $46 \%$ of students and parents reported eating fruit less often than 3 times a week (Figures 1 and 2). This result is consistent with other studies in Chile. For example, Olivares et al. (2004) also indicated a low consumption of fruits and vegetables in schools in the metropolitan area, less than $50 \%$ of the recommendation by WHO.
Table 1. Descriptive Statistics of survey results.

(a) Student's descriptive statistics

\begin{tabular}{lcccc}
\hline & Average & $\begin{array}{c}\text { Standard } \\
\text { Deviation. }\end{array}$ & Simetry & Kurtosis \\
\hline LS1 & 4.01 & 2.38 & -0.03 & -1.54 \\
LS2 & 5.66 & 1.98 & -1.35 & 0.47 \\
LS3 & 5.38 & 2.08 & -1.01 & -0.33 \\
LS4 & 4.42 & 2.49 & -0.29 & -1.58 \\
LS5 & 5.84 & 1.86 & -1.56 & 1.18 \\
LS6 & 5.97 & 1.67 & -1.74 & 2.12 \\
LS7 & 4.46 & 2.04 & -0.34 & -1.05 \\
LS8 & 4.52 & 2.37 & -0.38 & -1.42 \\
LS9 & 2.72 & 2.21 & 0.88 & -0.78 \\
LS10 & 3.41 & 2.17 & 0.31 & -1.22 \\
LS11 & 4.68 & 2.38 & -0.49 & -1.35 \\
LS12 & 5.22 & 2.17 & -0.89 & -0.67 \\
LS13 & 5.79 & 1.97 & -1.46 & 0.74 \\
LS14 & 3.23 & 2.09 & 0.46 & -1.06 \\
CAM1 & 5.22 & 2.15 & -0.89 & -0.58 \\
CAM2 & 5.41 & 2.00 & -1.09 & -0.03 \\
CAM3 & 5.76 & 1.82 & -1.43 & 0.98 \\
CAM4 & 5.97 & 1.88 & -1.80 & 1.87 \\
\hline & & & & \\
\hline
\end{tabular}

(b) Parent's descriptive statistics

\begin{tabular}{|c|c|c|c|c|}
\hline & Average & $\begin{array}{l}\text { Standard } \\
\text { deviation }\end{array}$ & Simetry & Kurtosis \\
\hline LS1 & 4.80 & 2.46 & -0.54 & -1.38 \\
\hline LS2 & 6.15 & 1.60 & -2.01 & 3.28 \\
\hline LS3 & 6.56 & 1.14 & -2.33 & 6.64 \\
\hline LS4 & 3.95 & 2.34 & 0.01 & -1.50 \\
\hline LS5 & 5.98 & 1.71 & -1.66 & 1.73 \\
\hline LS6 & 6.53 & 1.20 & -2.50 & 8.97 \\
\hline LS7 & 4.29 & 2.27 & -0.20 & -1.40 \\
\hline LS8 & 5.67 & 1.86 & -1.40 & 0.88 \\
\hline LS9 & 3.91 & 2.31 & 0.00 & -1.48 \\
\hline LS10 & 3.95 & 2.53 & -0.02 & -1.72 \\
\hline LS11 & 3.07 & 2.27 & 0.62 & -1.12 \\
\hline LS12 & 4.43 & 2.54 & -0.29 & -1.64 \\
\hline LS13 & 6.02 & 1.81 & -1.83 & 2.12 \\
\hline LS14 & 3.06 & 2.57 & 0.63 & -1.41 \\
\hline CAM1 & 6.16 & 1.68 & -2.11 & 3.44 \\
\hline CAM2 & 5.67 & 2.04 & -1.47 & 0.72 \\
\hline CAM3 & 6.10 & 1.76 & -2.07 & 3.07 \\
\hline CAM4 & 5.96 & 1.96 & -1.79 & 1.76 \\
\hline
\end{tabular}




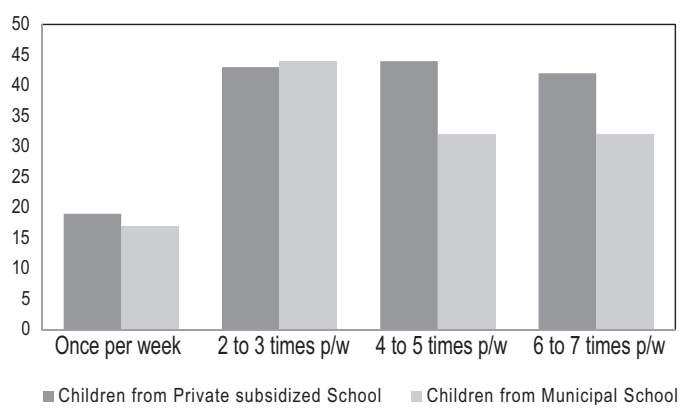

Figure 1. Consumption frequency of fruits and vegetables of children of each school.

Atalah et al. (1999) indicated that schools in the Aysen region also have a low fruit and vegetable consumption.

An analysis of average LS responses, which reflect students' thoughts regarding their eating habits, showed some weaknesses in household consumption patterns and social influence (Table 2). For example, fruits are not a common food at breakfast or snack time (LS1 and LS9). Also, children do not usually see their classmates having fruit as a snack either (LS14). At the Parent level, the responses in this regard were consistent with those given by the children (Table 3). Parents reported that, in general, fruits are not a common food at breakfast for their children (LS1), and they do not send fruit as a snack to school (LS9). The family influence in the development of eating behaviors is low, as families did not have a routine of eating breakfast together (LS4), a perfect time for parents to influence what their children eat.

To measure the willingness to change children's and parents' eating habits and increase their fruit intake, four statements were presented in the third section of the survey. Tables 2 and 3 present the evaluations of the choices by the children and parents for these claims, respectively. All statements were evaluated with averages over 4.5 by children, emphasizing the statement "If fruit prices went down" (CAM1), which obtained the lowest rating (4.5). The statement "If my household income increased" (CAM4), referring to a possible increase of desserts

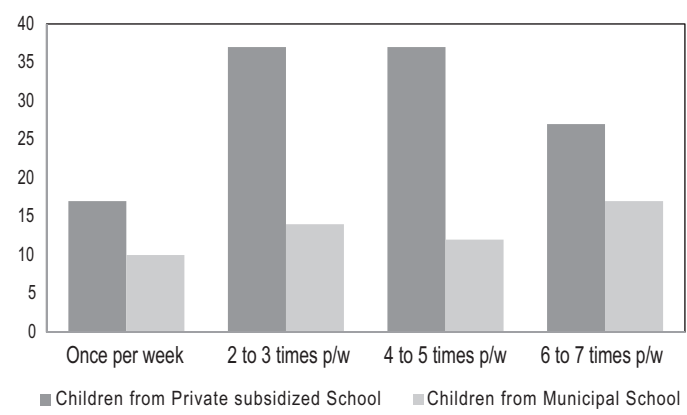

Figure 2. Consumption frequency of fruits and vegetables of children's parents of each school.

containing fruits, was the claim best evaluated by the children to increase their consumption. For parents, all claims were well evaluated (5.0). The best evaluated claim to increase fruit consumption by the parents proved to be the CAM1 statement, which refers to a decrease in the price of fruit. The statement that referred to the greater advertisement of these foods was less influential among parents for increasing fruit consumption.

Table 4 presents the results obtained by performing an analysis of variance on the responses of the statements made in sections one and three of the survey. The null hypothesis stating that the means of the responses given by the children associated with these variables are equal is not accepted. The responses of the public school children to these claims turn out to be significantly lower than the responses of children from the co-funded school. Compared to the children of the semi-private school, the public school children agreed less with the statements about availability of fruits at home, fruit purchases by parents, taking into account the preferences of the children, preparing fruit desserts at home, children's demands to eat fruits, consumption of fruit as a snack if brought by the children and the school promoting consumption.

When assessing the propensity to change among students, only the statement about increasing fruit consumption if classmates ate more fruits as snacks showed a statistically significant difference. This statement received a 4.7 grade by the 
Table 2. Student's mean results of LS and CAM statements by genre and school.

\begin{tabular}{|c|c|c|c|c|c|}
\hline & \multirow[b]{2}{*}{ Statements } & \multicolumn{2}{|c|}{ Co-Funded } & \multicolumn{2}{|c|}{ Public } \\
\hline & & Boys $n=69$ & Girls $n=79$ & Boys $n=56$ & Girls $n=69$ \\
\hline LS1 & Fruits are a recurrent for breakfast. & 3.80 & 4.65 & 3.18 & 4.19 \\
\hline LS2 & $\begin{array}{l}\text { On weekends I eat my favorite foods, } \\
\text { accompanied by my parents }\end{array}$ & 5.65 & 5.63 & 6.20 & 5.25 \\
\hline LS3 & In summer I like to eat more fruit. & 5.28 & 5.73 & 5.23 & 5.22 \\
\hline LS4 & At home we usually eat breakfast together. & 4.41 & 4.37 & 4.30 & 4.61 \\
\hline LS5 & At home there always is fruit & 5.86 & 6.39 & 5.66 & 5.35 \\
\hline LS6 & My parents buy fruits that I most like. & 6.01 & 6.25 & 5.61 & 5.88 \\
\hline LS7 & .My parents serve fruit desserts & 4.42 & 5.33 & 3.73 & 4.10 \\
\hline LS8 & I At home I must eat fruit & 5.32 & 5.37 & 3.59 & 3.51 \\
\hline LS9 & I take fruit as snacks to school & 2.68 & 3.22 & 1.96 & 2.81 \\
\hline LS10 & I prefer sweets over fruits & 3.67 & 3.09 & 2.96 & 3.90 \\
\hline LS11 & If my snack is fruits I always eat it & 4.64 & 5.24 & 4.41 & 4.30 \\
\hline LS12 & My favorite desserts have fruits & 5.03 & 5.65 & 5.00 & 5.12 \\
\hline LS13 & My school promotes the consumption of fruits & 5.99 & 6.34 & 5.32 & 5.36 \\
\hline LS14 & My classmates have fruit snacks & 3.45 & 3.39 & 2.80 & 3.17 \\
\hline CAM1 & If my classmates eat more fruit & 5.17 & 6.00 & 4.45 & 5.00 \\
\hline CAM2 & If there were more fruit publicity & 5.29 & 5.62 & 5.07 & 5.55 \\
\hline CAM3 & If they explained how healthy they are & 5.59 & 6.15 & 5.34 & 5.81 \\
\hline CAM4 & If at home they served more fruit desserts & 5.68 & 6.52 & 5.21 & 6.23 \\
\hline
\end{tabular}

public school and a 5.6 by the co-funded school, which is evidence of the presence of differences between both environments regarding the perception of classmate influence on children and how it may affect fruit consumption. These results are consistent with those obtained by Reinaerts et al. (2006) who concluded that social factors such as school type and education by teachers and parents, among others, significantly affect the level of fruit consumption among children.

To determine family influence on children's fruit consumption, an analysis of variance of the answers given by children and parents was performed. This analysis is conducted only for statements 1, 2, 3, 4, 5, 6, 9 and 13 in section 1 of the survey and statements 2 and 3 of section 3 of the survey, which showed the potential to increase fruit consumption. The results are presented in Tables 5 and 6 for the public and co-funded schools, respectively.

In the case of the public school, statements such as "fruits are common foods at my breakfast" (LS1), "in summer I like to eat more fruits" (LS3) and "my parents buy the fruits that I like the most" 
Table 3. Parent's mean results of LS and CAM statements by genre and school.

\begin{tabular}{|c|c|c|c|}
\hline & Statements & $\begin{array}{c}\text { Co-Funded } \\
\text { Parents } n=171\end{array}$ & $\begin{array}{c}\text { Public } \\
\text { Parents } n=53\end{array}$ \\
\hline LS1 & Fruits are recurrent for my children's breakfast. & 4.58 & 5.26 \\
\hline LS2 & On weekends our family has lunch together & 6.34 & 5.72 \\
\hline LS3 & In summer I like to eat more fruit. & 6.50 & 6.70 \\
\hline LS4 & At home we usually eat breakfast together. & 3.99 & 3.85 \\
\hline LS5 & At home there always is fruit & 6.02 & 5.91 \\
\hline LS6 & I buy fruits that my children like. & 6.45 & 6.70 \\
\hline LS7 & I spend more money on fruits than on meat & 4.22 & 4.43 \\
\hline LS8 & In general I buy the cheapest quality fruit & 5.50 & 6.06 \\
\hline LS9 & I send fruit as snacks to school & 4.07 & 3.55 \\
\hline LS10 & It's a battle to make my kids eat fruits & 3.95 & 3.96 \\
\hline LS11 & My children ask for fruit snacks & 3.15 & 2.89 \\
\hline LS12 & The fruit I buy is never enough & 4.28 & 4.75 \\
\hline LS13 & My children's scholl promotes fruit consumption & 6.14 & 5.77 \\
\hline LS14 & My classmates have fruit snacks & 2.65 & 3.96 \\
\hline CAM1 & If my classmates eat more fruit & 6.05 & 6.42 \\
\hline CAM2 & If there were more fruit publicity & 5.65 & 5.70 \\
\hline CAM3 & If they explained how healthy they are & 6.10 & 6.09 \\
\hline CAM4 & If at home they served more fruit desserts & 5.77 & 6.38 \\
\hline
\end{tabular}

Table 4. ANOVA results for student's answers.

\begin{tabular}{|c|c|c|c|c|c|}
\hline \multirow{2}{*}{$\begin{array}{l}\mathrm{N}^{\circ} \\
\text { Statement }\end{array}$} & \multicolumn{3}{|c|}{ Average } & \multirow[b]{2}{*}{ F } & \multirow[b]{2}{*}{ Sig. } \\
\hline & Public & Co-Funded & Total & & \\
\hline LS1 & 3.7769 & 4.2759 & 4.0489 & 2.962 & 0.086 \\
\hline LS2 & 5.6777 & 5.6966 & 5.6880 & 0.006 & 0.938 \\
\hline LS3 & 5.2975 & 5.5655 & 5.4436 & 1.122 & 0.291 \\
\hline LS4 & 4.5372 & 4.3655 & 4.4436 & 0.314 & 0.576 \\
\hline LS5* & 5.5372 & 6.1241 & 5.8571 & 6.944 & 0.009 \\
\hline LS6* & 5.7355 & 6.1517 & 5.9624 & 4.064 & 0.045 \\
\hline LS7* & 3.9091 & 4.9448 & 4.4737 & 18.038 & 0.000 \\
\hline LS 8* & 3.5785 & 5.3724 & 4.5564 & 44.354 & 0.000 \\
\hline LS9 & 2.4793 & 2.9724 & 2.7481 & 3.312 & 0.070 \\
\hline LS10 & 3.4463 & 3.3655 & 3.4023 & 0.093 & 0.760 \\
\hline LS11* & 4.3554 & 5.0414 & 4.7293 & 5.630 & 0.018 \\
\hline LS12 & 5.1488 & 5.4000 & 5.2857 & 0.914 & 0.340 \\
\hline LS13* & 5.2893 & 6.1586 & 5.7632 & 13.291 & 0.000 \\
\hline LS14 & 3.0661 & 3.4276 & 3.2632 & 1.994 & 0.159 \\
\hline CAM1* & 4.7521 & 5.6690 & 5.2519 & 12.879 & 0.000 \\
\hline CAM2 & 5.3802 & 5.5241 & 5.4586 & 0.361 & 0.548 \\
\hline CAM3 & 5.7190 & 5.9310 & 5.8346 & 0.984 & 0.322 \\
\hline CAM4 & 5.7686 & 6.1931 & 6.0000 & 3.525 & 0.062 \\
\hline $\mathrm{N}$ & 121 & 145 & 266 & & \\
\hline
\end{tabular}


Table 5. ANOVA results for Municipal School parent and children's responses.

\begin{tabular}{|c|c|c|c|c|c|}
\hline \multirow{2}{*}{$\begin{array}{l}\mathrm{N}^{\circ} \\
\text { Statement }\end{array}$} & \multicolumn{3}{|c|}{ Average } & \multirow[b]{2}{*}{ F } & \multirow[b]{2}{*}{ Sig. } \\
\hline & Children & Parents & Total & & \\
\hline LS1* & 3.8431 & 5.1961 & 4.5196 & 7.064 & 0.009 \\
\hline LS2 & 5.8431 & 5.6667 & 5.7549 & 0.196 & 0.659 \\
\hline LS3* & 5.3137 & 6.6863 & 6.0000 & 15.109 & 0.000 \\
\hline LS4 & 4.8039 & 3.9216 & 4.3627 & 3.256 & 0.074 \\
\hline LS5 & 5.5686 & 5.8627 & 5.7157 & 0.535 & 0.466 \\
\hline LS6* & 5.8039 & 6.6863 & 6.2451 & 8.037 & 0.006 \\
\hline LS9 & 2.9412 & 3.6471 & 3.2941 & 2.137 & 0.147 \\
\hline LS13 & 5.4902 & 5.8431 & 5.6667 & 0.726 & 0.396 \\
\hline CAM2 & 5.4706 & 5.7647 & 5.6176 & 0.600 & 0.441 \\
\hline CAM3 & 5.7255 & 6.0588 & 5.8922 & 0.877 & 0.351 \\
\hline $\mathrm{N}$ & 51 & 51 & 102 & & \\
\hline
\end{tabular}

(LS6) presented results where the null hypothesis, which states that the means of the answers given by children associated with these variables are the same as their parents with a $\%$ significance level, is not accepted. Children agreed less with these statements than their parents. In statements intended to measure the potential to increase fruit consumption (CAM1 and CAM3), parents and children did now show statistically different responses.

In the case of the semi-private school, statements that address topics such as "the weekend my family meets for lunch" (LS2), "in summer, I like to eat more fruit" (LS3), and "I usually bring (send) fruit as a snack (to my children)" (LS9), had significantly lower means for children as compared to their parents.

When analyzing the differences in the responses given by parents and children to statements related to family influence on the consumption of fruits, it is concluded that parents and children perceive issues in different ways. According to Olivares et al. (1999), a child's early experience with food, especially food practices of parents, is fundamental in the eating habit developed by the individual. The mother is a primary part in the child's feeding practices and in the social context of the family. This research shows evidence that
Table 6. ANOVA results for Private subsidized School parent and children's responses.

\begin{tabular}{|c|c|c|c|c|c|}
\hline \multirow{2}{*}{$\begin{array}{l}\mathrm{N}^{\circ} \\
\text { Statement }\end{array}$} & \multicolumn{3}{|c|}{ Average } & \multirow[b]{2}{*}{$\mathrm{F}$} & \multirow{2}{*}{ Sig. } \\
\hline & Children & Parents & Total & & \\
\hline LS1 & 4.3947 & 4.6316 & 4.5132 & 0.635 & 0.426 \\
\hline LS2* & 5.6579 & 6.3596 & 6.0088 & 10.071 & 0.002 \\
\hline LS3* & 5.6228 & 6.5526 & 6.0877 & 19.784 & 0.000 \\
\hline LS4 & 4.4561 & 3.9825 & 4.2193 & 2.247 & 0.135 \\
\hline LS5 & 6.1667 & 6.0965 & 6.1316 & 0.124 & 0.725 \\
\hline LS6 & 6.1754 & 6.4912 & 6.3333 & 3.252 & 0.073 \\
\hline LS9* & 3.2281 & 4.1140 & 3.6711 & 8.781 & 0.003 \\
\hline LS13 & 6.0965 & 6.2018 & 6.1491 & 0.234 & 0.629 \\
\hline CAM2 & 5.6228 & 5.7018 & 5.6623 & 0.092 & 0.761 \\
\hline CAM3 & 6.0439 & 6.1491 & 6.0965 & 0.246 & 0.620 \\
\hline $\mathrm{N}$ & 114 & 114 & 228 & & \\
\hline
\end{tabular}

family influences the decision making of fruit consumption among children, in accordance with the statement made by Olivares et al. (2006), who said that children with greater family support consume more fruits. Although this is not the only factor that influences consumption, it is a major source of healthy eating habits for children.

Table 7 presents the results of the cluster analysis for children and parents. The clusters of children are those who receive support from their parents to eat fruits and those who receive little or no support from their parents to consume these foods. The results indicated that family influence affects the consumption decisions of these children, which can be demonstrated by the differences in the mean of the responses to the statements that describe this factor, especially in statements that reflect the customs of family life, such as LS4, referring to having breakfast with the family. This is a time when children could be persuaded by parental influence to eat fruits during the meal. Differences are also observed regarding the statement related to the preparation of fruit for dessert (LS7), which is highly valued by the children who have support, while poorly evaluated by the children who receive little or no support. A similar situation is observed for statement LS8, which refers to the parents' demands 
towards fruit consumption for their children. Also, using the Chi-square test, there is a significant association between the of children's frequency of consumption and the cluster that they belong to $(\mathrm{P}=0.009, \mathrm{P} \leq 0.05)$. We conclude that children with greater family support consume more fruits.

To reaffirm these results, a cluster analysis was performed for the children's parents. A sample of 165 parents was segmented into two clusters: (1) Parents who support the consumption of fruit for their children and (2) parents who do not support the consumption of fruit for their children. These clusters were evaluated based on statements that correlate family influence and fruit consumption. Table 7 shows that the results are grouped into two homogeneous groups in terms of quantity, indicating that despite parental influence on fruit consumption, other influences also encourage children to increase their fruit consumption.

There were statements that differed among parents that belonged to the clusters (Table 7). The statements LS1 and LS4, regarding the inclusion of fruit at breakfast for children and family integration at the time of the meal, obtained low scores for parents who do not support the consumption of fruit. As for the inclusion of fruit as a snack, statements LS9 and LS11 were given low evaluations by parents who do not support fruit consumption. One example of this low score is LS11, "My children ask me to send fruit as a snack", which reveals that parents are aware that their children do not include fruits as part of their meals. This statement score is supported by the low score assigned by the same group of parents to the statement LS9, "I usually send fruit as a snack for my children". Parents are aware that their children do not ask for this food and that they do not encourage them to do so. The result of the Chi-square test showed that there is a significant association among the consumption frequencies revealed by the children and the cluster to which their parents belong $(\mathrm{P}=0.009$, $\mathrm{P} \leq 0.05$ ). This means that parents who support fruit consumption and those whose support is limited or simply do not support it at all were in accordance with the consumption frequencies revealed by their children.

The communication strategies that could be used to improve the frequency of fruit consumption

Table 7. Conglomerate results for two segments.

\begin{tabular}{|c|c|c|c|c|c|}
\hline \multirow[b]{2}{*}{ Statement } & \multicolumn{2}{|c|}{ Clusters (Children) } & \multirow[b]{2}{*}{ Statement } & \multicolumn{2}{|c|}{ Clusters (Parents) } \\
\hline & $\begin{array}{c}\text { 1: Are } \\
\text { supported }\end{array}$ & $\begin{array}{c}\text { 2: Are not or are } \\
\text { scarcely supported }\end{array}$ & & $\begin{array}{c}\text { 1: Support } \\
\text { Consumption }\end{array}$ & $\begin{array}{l}\text { 2: Do not support } \\
\text { Consumption }\end{array}$ \\
\hline LS1 & 4.55 & 3.74 & LS1* & 6.04 & 3.56 \\
\hline LS2 & 6.18 & 5.02 & LS2 & 6.41 & 5.88 \\
\hline LS4* & 6.09 & 2.27 & LS4* & 5.14 & 2.77 \\
\hline LS5 & 6.43 & 5.30 & LS5 & 6.16 & 5.89 \\
\hline LS6 & 6.28 & 5.73 & LS6 & 6.64 & 6.46 \\
\hline LS7* & 5.39 & 3.55 & LS7 & 4.93 & 3.78 \\
\hline LS8* & 5.64 & 3.91 & LS8 & 5.83 & 5.63 \\
\hline- & - & - & LS9* & 5.41 & 2.51 \\
\hline- & - & - & LS10 & 3.53 & 4.24 \\
\hline- & - & - & LS11* & 4.65 & 1.61 \\
\hline- & - & - & LS12 & 5.29 & 3.61 \\
\hline- & - & - & LS14 & 3.61 & 2.54 \\
\hline $\begin{array}{l}\text { Total } \\
\text { Children } \\
\text { in Cluster }\end{array}$ & 99 & 66 & $\begin{array}{l}\text { Total Parents } \\
\text { in Cluster }\end{array}$ & 83 & 82 \\
\hline
\end{tabular}


should not focus exclusively on the functional attributes of fruits. Children and parents already have knowledge of these concepts. Instead communication efforts should be aimed at increasing the frequency of fruit consumption in the family; parents should take a leading role in promoting the consumption of these foods among children. These communication campaigns should emphasize the importance of the educational role of the parents during family times, such as breakfast, lunch and dinner. Parents should first exercise authority in the consumption of fruits, strengthen the intrinsic benefits of these foods and show by example.

To learn how the schools where the children study influence the consumption of fruits, we performed a cluster analysis using the statements that reflect this influence. Depending on the outcome, the sample was segmented into two groups of children: (1) Children who do not receive support from the school to eat fruits and (2) children who receive support from the school to eat fruits. As evidenced in Table 8, the segment of children who have no support for the consumption of fruits at school gave low scores to the statement that refers to bringing fruit as a snack to school. From the Chi-square test, there appears to be a significant association between the consumption frequencies revealed by the children and the cluster to which they belong $(\mathrm{P}=0.009, \mathrm{P} \leq 0.05)$.

From the clusters of children that received encouragement from their school to consume

Table 8. Conglomerate results for two segments (children)

\begin{tabular}{lcc}
\hline \multirow{2}{*}{ Statement } & \multicolumn{2}{c}{ Clusters } \\
\cline { 2 - 3 } & $\begin{array}{cc}\text { 1: Do not receive } \\
\text { support at school }\end{array}$ & $\begin{array}{c}\text { 2: Recieves } \\
\text { support at school }\end{array}$ \\
\hline
\end{tabular}

\begin{tabular}{lcc}
\hline $\begin{array}{l}\text { LS13: My school } \\
\text { promotes the } \\
\text { consumption of fruits }\end{array}$ & 5.22 & 6.44 \\
$\begin{array}{l}\text { LS14: My classmates } \\
\text { take fruits as snacks to } \\
\text { school }\end{array}$ & 1.78 & 5.01 \\
$\begin{array}{l}\text { Total Children in } \\
\text { Clusters }\end{array}$ & 72 & \\
\hline
\end{tabular}

fruits, over $50 \%$ of the sample belongs to the co-funded school. Several studies (e.g., Nasrin et al., 2003, French and Stables, 2003; Burchett, 2003; Reinaerts et al., 2006) have concluded that an increased availability of fruits results in their increased consumption; the results reveal that, despite differences in the perception of support received at school, children belonging to both clusters reveal high intakes of fruits (more than 4 times per week), indicating that the social environment is not the only factor that influences fruit consumption among children.

These results indicate that parental influence is an action that could influence the increased consumption of fruit among children. Parents may reinforce the habits by sending fruit-based snacks to school. The influence of classmates is a source of motivation towards greater consumption, as children with a low fruit consumption frequency imitate the behavior of other children. This requires monitoring and commitment by the educational establishment until the habit is created in children. Also, the support to consume fruit should not be limited to a few parents and students. A coordinated and joint action by the parents through the parent center is essential, and the school that the child attends should support these initiatives. Burchett (2003) described that factors such as familiarity with fruits, increased exposure and accessibility and the preparation method have important effects in generating preferences, which is consistent with the results presented. It is concluded that providing ready to eat fruits and their inclusion in desserts and homemade meals plays an essential role in generating fruit preferences and consumption habits among children.

To find out how fruit consumption habits among children influences the decision to eat these foods, a cluster analysis was performed considering the statements that address this factor. For this analysis, two groups or clusters were examined: (1) They do not have fruit eating habits and (2) they have fruit eating habits. Topics such as "fruit 
consumption in the summer", "bringing fruit to school as a snack" and "children's favorite desserts containing fruit", were evaluated with high marks by children who have fruit-eating habits (Table 9). The LS10 statement, regarding the preference of sweets over fruits, received a high score from children without fruit consumption habits. The result of the Chi-square test indicated a significant association between the consumption frequencies revealed by the children and the cluster to which they belong, according to their fruit consumption habits $(\mathrm{P}=0.009, \mathrm{P} \leq 0.05)$. Children who have solid habits of fruit consumption showed higher frequencies of consumption of these foods per week.

Children with frequent fruit consumption habits are concluded to eat fruits every week. Topics such as fruit consumption in the summer, bringing fruits to school as snacks, and preparing their favorite fruit-based desserts were evaluated with high scores by children with fruit consumption habits. There is a large difference in the evaluation of the statement that refers to preferring fruit snacks versus fruit made by children without fruit habits (4.4) versus the low grade assigned by children who have a habit of fruit consumption (2.5).

Regarding the relative importance of factors that could affect fruit consumption among children, Figures 3 and 4 show that attributes such as

Table 9. Conglomerate results for two segments by consumption habits.

\begin{tabular}{lcc}
\hline & \multicolumn{2}{c}{ Clusters } \\
\cline { 2 - 3 } Statement & $\begin{array}{c}\text { 1: Do not have } \\
\text { consumption habit }\end{array}$ & $\begin{array}{c}\text { 2: Have } \\
\text { consumption habit }\end{array}$ \\
\hline LS3 & 4.26 & 6.29 \\
LS9 & 1.81 & 3.94 \\
LS10 & 4.44 & 2.55 \\
LS12 & 3.03 & 6.38 \\
$\begin{array}{l}\text { Total Children } \\
\text { in Clusters }\end{array}$ & 62 & 103 \\
\hline
\end{tabular}

"they are good for my health" and "they are rich in vitamins," were listed as the most important for the children surveyed in both schools. The attribute "they are essential in my diet," despite being linked to the concept of "they are good for my health," did not present a high level of importance, ranking only seventh place for the public school and fifth place for the co-funded school.

For the public school, the attribute that resulted in third place of importance was "they are fresh and juicy", an attribute that scored negative and ranked fourth for students of the co-funded school. The statement "they are low in calories" obtained third place, ranking higher than "they are fresh and juicy." Availability is not an attribute valued by the children, which resulted in low scores obtained by the statement "they are cheap and accessible" for both samples in this study.

Regarding the relative importance of factors that may affect fruit consumption according to parents, Figures 5 and 6, show that statements such as "they are good for my health" and "they are rich in vitamins" were highly rated by the parents of the surveyed students. Although the positions are reversed in order of importance, both were ranked in the top two spots. These results are in concordance with the responses of the children attending these schools.

It is emphasized that in the case of the public school, the attribute "they are low in calories" was highly valued, ranking number three. This coincides with what was expressed by the students of this school, where this statement ranks in the same place. For parents of the public school, this attribute was ranked number eight, three places lower than what the children expressed, who ranked it number five.

Only for parents of the co-funded school, the statement "they are essential in my diet" plays an important role. As for the children of both schools and parents of the public school, this statement scored very low compared to the other statements; they did not relate it to statements 


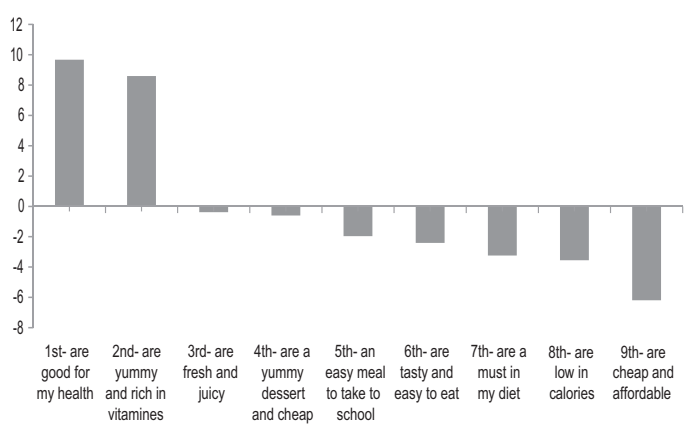

Figure 3.Municipal school Best Worst Results for students.

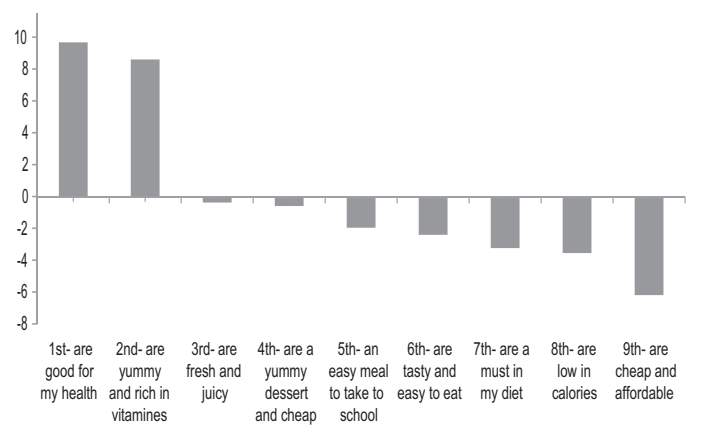

Figure 5. Municipal school Best Worst Results for parents.

such as "they are good for my health" or "they are low in calories."

As expressed by the children from both schools, the attribute "they are fresh and juicy" was valued by parents. The attribute "they are a convenient snack to send to school" received medium evaluation scores from parents of both schools, and slightly lower from children, indicating that neither the children nor the parents favor fruits as a snack.

The attributes "they are tasty and easy to eat" and "they are a delicious and an inexpensive dessert" received low scores from the co-funded school. Both attributes received higher scores at the public school, which is consistent with the views expressed by the surveyed children attending the same school. Similar to what was

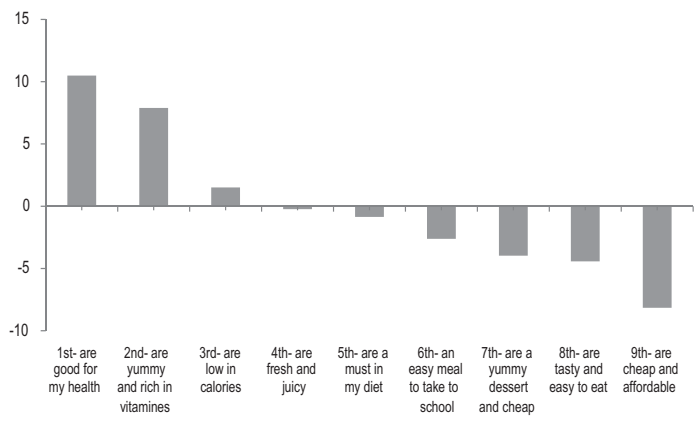

Figure 4. Subsidized private school Best Worst Results for students.

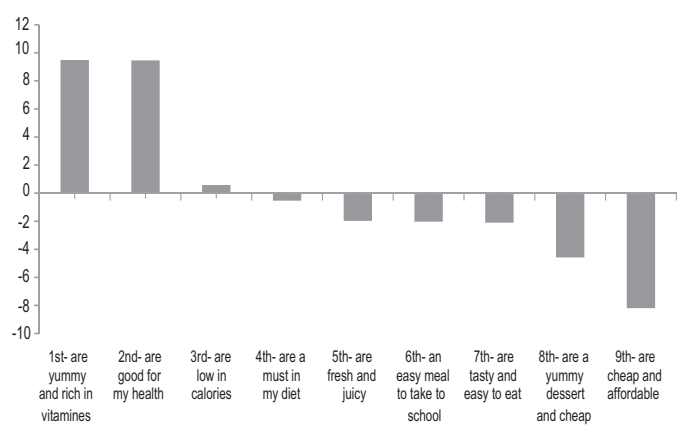

Figure 6. Subsidized private school Best Worst Results for parents

expressed by the children of both schools, for the parents, the attribute "they are inexpensive and accessible" registered a low score compared to other attributes.

The results of the study are of great concern as $50 \%$ of parents and children surveyed said they have a low fruit intake. This situation requires concrete and coordinated actions to improve this indicator. Some actions that should result from the analysis of the information gathered in this study are proposed.

Finally, it is important to consider that the results of this study cannot be generalized to the entire school community in Chile. It is necessary to extend this study to other demographic and geographic segments to diagnose the real situation of fruit consumption among the school-age population in Chile. 


\title{
Resumen
}

\begin{abstract}
A. Beaujanot, G. Donoso y A. del Valle. 2012. Factores que inciden en el consumo de frutas en escolares de la Región Metropolitana: El caso de dos colegios en la comuna de Lo Prado. Cien. Inv. Agr. 39(1): 19-35. Esta investigación identifica la influencia de los hábitos ambientales, sociales y de los consumidores en la decisión de los niños en el consumo de frutas. También se estudian atributos que influyen en el consumo de frutas para niños en la escuela y su disposición a cambiar los comportamientos de consumo. El estudio se lleva a cabo en alumnos de $5^{\circ}$ y $8^{\circ}$ grado que asisten a una escuela primaria público y otra privada en el municipio de Lo Prado, Santiago. El nivel de consumo de frutas depende en gran medida en el apoyo a la familia y la escuela que los niños reciban. Atributos tales como: "Las frutas son buenas para mi salud" y "Las frutas son ricas en vitaminas", son los más importantes para los padres y los niños que asisten a escuelas públicas y privadas. Desde una perspectiva estratégica, la investigación concluye que se necesita un enfoque más proactivo y coherente de los padres y las comunidades escolares para fomentar el consumo de fruta entre los niños. Esta perspectiva debe mantener o mejorar el consumo de los niños de la fruta. Además, se reveló que los comportamientos de los padres y de la escuela hacia la preparación de postres con frutas es una forma efectiva de aumentar el consumo de frutas.
\end{abstract}

Palabras clave: Determinantes del consumo de frutas por parte de los niños, ingesta de verduras y fruta por parte de los niños, patrones alimentarios de los niños.

\section{References}

Atalah, E., C. Arteaga, A. Rebolledo, S. Delfín, and R. Ramos. 1999. Patrones alimentarios y de actividad física en escolares de la región de Aysén. Revista Chilena de Pediatría 70(6): 483-490.

Auger, P., T. Devinney and J. Louviere. 2004. Consumer Social Beliefs: An International Investigation using Best-Worst Scaling Methodology. Working Paper, Melbourne Business School. Melbourne, Australia: University of Melbourne. $44 \mathrm{pp}$.

Babbie, E. 2000. Fundamentos de la Investigación Social. Primera Edición. Ediciones Thomson Paraninfo, México. $473 \mathrm{pp}$.

Banco Mundial. 2011. Datos. Clasificación de países. Available online at: http://datos.bancomundial. org/quienes-somos/clasificacion-paises (Website accessed: October 12, 2011)

Barnard, K. ,and S. Eyres. 1979. Child Health Assessment, Part 2: The First Year of Life. Hyattsiville MD: US. Departament of Health, Education, and Welfare, Public Health Service, HRA,
Bureau of Health Manpower.Available online at: http://eric.ed.gov/ERICDocs/data/ericdocs 2 sql/ content_storage_01/0000019b/80/32 ee/20.pdf (Website accessed: January11, 2009).

Bower, J., and J. Ferguson. 2008. Children's perceptions of fresh fruit and fruit snack. Nutrition \& Food Science 38: 256-263.

Burchett, H. 2003. Increasing fruit and vegetable consumption among British primary schoolchildren: a Review. Health Education 103:99-109.

Cervantes, M., M. Sulé, and A. González. 1996. Hábitos de los consumidores Castellano-Leoneses en la compra de fruta fresca. V Congreso de Economía Regional (Ávila, 1996). El Sector de Servicios en Castilla y León. Comunicaciones 2, p.1145-1156.

Cochran, W. 1963. Sampling Techniques. Second Edition. Wiley Editions, New York, USA. 413 pp.

de Droog, S., P. Valkenburg, and M. Buijzen. 2011. Using brand characters to promote young children's liking of and purchase requests for fruit. Journal of Health Communication, 16:79-89. 
del Valle, A. 2009. Factores que inciden en el consumo de frutas en escolares de la Región Metropolitana: El caso de dos colegios en la comuna de Lo Prado. Tesis para optar al grado de Magíster en Economía Agraria, Departamento de Economía Agraria, Pontificia Universidad Católica de Chile. 107 pp.

Díaz, M. 2002. Preferencias alimentarias como estudio al patrón dietético. Revista Española de Nutrición Comunitaria 8(1-2):29-34.

Domínguez - Vásquez P., S. Olivares, and JL. Santos. 2008. Influencia familiar sobre la c o n d u c t a alimentaria y su relación con la obesidad infantil. Archivos Latinoamericanos de Nutrición 58 (3):31-36.

French, S., and G. Stables. 2003. Environmental interventions to promote vegetable and fruit consumption among youth in school settings. Preventive Medicine 37: 593-610.

Gilbert, C., M. Sánchez, C. Lehoux, A. Hegyi, A. Åström, G. Hall, G. Merino, A. Masson, L. Fontaine, and T. Kuti. 2007. Qualitative research investigating food choices and preferences of adolescents in Europe. Available online at: http://helenastudy.com (Website accessed: January 5,2009 ).

Herrero, C. 2008. El horario infantil en televisión: de la falta de imaginación a la irresponsabilidad de los mensajes publicitarios. Trastornos de la Conducta Alimentaria 7: 751-766.

INE. 2002. Censo Poblacional: Síntesis de Resultados - Características Demográficas. Available online at: http://www.ine.cl/cd2002/poblacion. pdf (Website accessed: July 14, 2010).

Jaeger, S., and A. Cardello. 2009. Direct and Indirect hedonic scaling methods: A comparison of the labeled affective magnitude (LAM) scale and best-worst scaling. Food Quality and Preference 20 (3):249-258.

JUNAEB. 2009. Estrategia de Intervención nutricional a través del ciclo vital. http://www.minsal. gob.cl/portal/url/page/minsalcl/g_proteccion/g_ alimentos/prot ciclo_vital.html (Website accessed: April, 15 2010).

Kain, J., S. Olivares, M. Castillo, and F. Vio. 2001. Validación y aplicación de instrumentos para eval- uar intervenciones educativas en obesidad infantil. Revista Chilena de Pediatría 72: 308-318.

Kain, J., L. Lera, J. Rojas, and R. Uauy. 2007. Obesidad en preescolares de la Región Metropolitana de Chile. Rev. Méd. Chile 135: 63-70.

Kline, R. B. 1998. Principles and practices of structural equation modeling. (1st ed.). New York: Guilford.

Lusk, J., and B. Briggeman. 2009. Food values. American Journal of Agricultural Economics 91:184-196.

López, P., L. Esqueda, F. Rivas, R. Chacón, and A. Buccé. 2004. Percepción del valor nutricional y preferencias de alimentos en escolares de quinto grado. Mérida. Venezuela. Med -ULA, Revista de la Facultad de Medicina Universidad de Los Andes 10 (1-4): 04-10.

Martín, R. 2007. La obesidad infantil y los trastornos de la conducta alimentaria abordados desde el Centro de Atención. Ágora de Enfermería 11: 1152-1153.

Meléndez, G. 2008. Factores asociados con sobrepeso y obesidad en el ambiente escolar. Editorial Médica Panamericana, México. 216 pp.

Moreno, L.A., I. Pigeot, and W. Ahrens. 2011. Childhood obesity: Etiology - Synthesis Part II, in. Springer Series on Epidemiology and Public Health 2: 483-492.

MIDEPLAN. 2002. Encuesta de caracterización socioeconómica nacional, CASEN 2000. Ministerio de Planificación Nacional, División Social, Departamento de Información Social, Gobierno de Chile, Santiago, Chile. Available online at: http://www.mideplan.cl (Website accessed: March 18, 2009).

MINEDUC. 2009. Ley de Subvenciones. Decreto con Fuerza de Ley $\mathrm{N}^{\circ}$ 2, de Educación de 2008. Available online at: http://www.comunidadescolar.cl (Website accessed: March 16, 2009).

Nasrin, O., M. Ghazi-Tabatabaiae, S. Eghtesadi, and S. Minaie. 2003. Psychosocial correlates of low fruit and vegetable intake among adolescent boys and girls in Tehran, Iran. Ecology of Food and Nutrition 42: 385-397.

Olivares, S., C. Albala, F. García, and I. Jofré. 1999. Publicidad televisiva y preferencias alimentarias 
en escolares de la Región Metropolitana. Revista Médica de Chile 127: 791-799.

Olivares, S., J. Kain, L. Lera, F. Pizarro, F. Vio, and C. Morón. 2004. Nutritional status, food consumption and physical activity among Chilean school children: A descriptive study. European Journal of Clinical Nutrition 58: 1278-1285.

Olivares, S., I. Zacarías, L. Lera, B. Leyton, R. Durán, and F. Vio. 2005. Estado nutricional y consumo de alimentos seleccionados en escolares de la región Metropolitana: línea base para un proyecto de promoción del consumo de pescado. Revista Chilena de Nutrición 32: 102-108.

Olivares, S., and N. Bustos. 2006. Consumo de verduras y frutas en grupos específicos de consumidores chilenos: elementos a considerar en su promoción. Revista Chilena de Nutrición 33: 260-264.

Olivares, S., N. Bustos, X. Moreno, L. Lera, and S. Cortez. 2006. Actitudes y prácticas sobre alimentación y actividad física en niños obesos y sus madres en Santiago, Chile. Revista Chilena de Nutrición 33: 170-179.

Olivares, S., N. Bustos, L. Lera, and M. Zelada. 2007. Estado nutricional, consumo de alimentos y actividad física en escolares mujeres de diferente nivel socioeconómico de Santiago de Chile. Revista Médica de Chile 135:71-78.
Osorio, J., G. Weisstaub, and C. Castillo. 2002. Desarrollo de la conducta alimentaria en la infancia y sus alteraciones. Revista Chilena de Nutrición 29: 280-285.

Palou, A, M.L. Bonet, F.S. Serra, and C. Picó. 2011. Genetics and nutrigenomics of obesity, en epidemiology of obesity in Children and adolescents. Springer Series on Epidemiology and Public Health 2: 253-290.

Patrick, H., and T. Nicklas. 2005. A Review of family and social determinants of children's eating patterns and diet quality. Journal of the American College of Nutrition 24: 83-92.

Reinaerts, E., J. Nooijer, A. van de Kar, and N. de Vries. 2006. Development of at school-based intervention to promote fruit and vegetable consumption: Exploring perceptions among 4-to-12year old children and their parents. Health Education 106: 345-356.

Vásquez, F., G. Salazar, M. Andrade, E. Díaz, and J. Rojas. 2004. Ingesta alimentaria de preescolares obesos asistentes a los Jardines Infantiles de la JUNJI. Revista Chilena de Nutrición 31: 100-108.

Yáñez, R., S. Olivares, I. Torres, M. Guevara, and N. Díaz. 2001. Consumo de alimentos en escolares chilenos: Su relación con las guías y la pirámide alimentaria. Revista Chilena de Nutrición 28: 422-428. 
